\title{
TIPOLOGI PINTU RUMAH TRADISIONAL DUSUN PUCUNG, SITUS MANUSIA PURBA SANGIRAN
}

\author{
Gun Faisal'; Dimas Wihardyanto $^{2}$; Muhammad Sani Roychansyah ${ }^{2}$ \\ ${ }^{1}$ Program Studi Arsitektur, Fakultas Teknik, Universitas Riau. \\ ${ }^{2}$ Jurusan Teknik Arsitektur dan Perencanaan, Fakultas Teknik, Universitas Gadjah Mada. \\ gunfaisal@gmail.com
}

\begin{abstract}
ABSTRAK
Pintu merupakan elemen penting dalam suatu bangunan, terutama rumah tinggal. Pintu adalah jalur sirkulasi antara ruang dalam dan luar bangunan. Rumah di Dusun Pucung memiliki pintu yang terbilang unik, baik dari segi jumlah, bentuk dan ornamennya, yang mana penggunaannya memiliki maksud dan tujuan tersendiri bagi setiap pemiliknya. Tujuan dari penelitian ini untuk mengklasifikasikan pintu rumah tradisional yang berada di Dusun Pucung. Pendekatan penelitian dilakukan secara kuantititatif dan kualitatif, pengambilan data melalui survey lapangan, diiringi dengan studi literatur, studi kawasan, teoritikal, studi empiris terhadapt laporan penelitian terdahulu. Analisa data diawali dengan perumusan karakter umum pintu bangunan kawasan, penentuan pintu bangunan yang sesuai kriteria penelitian, penggambaran ulang (redrawing), pengelompokan dan kategorisasi tipikal elemen pintu bangunan. Penelitian ini pada akhirnya dapat mentipekan desain elemen pintu rumah tradisional yang berada di kawasan konservasi Situs Manusia Purba Sangiran, yang termasuk kedalam kawasan World Heritage. Berdasarkan hasil penelitian, didapatkan 6 (enam) tipe pintu rumah tradisional Dusun Pucung. Tipe pintu tersebut berdasarkan 2 kategori, yaitu berdasarkan jumlah; pintu satu, tiga, serta lima, dan berdasarkan materialnya, ada pintu yang terbuat dari bambu (gedhek), kayu, dan kayukaca.
\end{abstract}

Kata kunci: Tipologi, Pintu, Rumah Tradisional, Desa Pucung

\begin{abstract}
Door is an important element in a building, especially a residential house. It is a circulation path between the interior and exterior of building. In Pucung Village, it has relatively unique function and meaning with a variety of ornaments, shapes, and amounts. The purpose of this study is to classify the types of doors and their elements, in this case the doors of traditional house in Pucung Village. Data were collected through field surveys, which were supported by the literature, theoretical studies and the results of empirical study. Analysis and formulation of the general characters of doors were done, and the doors were determined in accordance with appropriate criteria of study and re-drawn, so the grouping and categorization of typical elements of the doors could be done. As a result, the design of traditional doors in the conservation area of Sangiran Early Man site, which is included in the World Heritage area, can eventually be typified. Based on the results of the study, six types of traditional doors in Pucung Village were obtained. The types of doors were based on two categories. Based on number, there were doors with one, three, and five in number, while based on material, there were doors made from bamboo (gedhek), wood, and wood and glass.
\end{abstract}

Keywords: Typology, Door, Traditional House, Pucung Village

\section{Pendahuluan}

Pintu merupakan elemen yang tidak terlepaskan dalam suatu bangunan, setiap bangunan memiliki pintu. Rumah yang ada di Dusun Pucung memiliki pintu yang terbilang unik, baik dari segi jumlah, bentuk dan ornamennya, yang penggunaannya memiliki maksud dan tujuan tersendiri bagi setiap pemiliknya.

Masyarakat Dusun Pucung menyebut pintu dengan sebutan Gebyok. Dusun Pucung merupakan dusun yang terletak dikawasan inti Klaster Dayu, Situs 
Manusia Purba Sangiran.

Berdasarkan Surat Keputusan Menteri Pendidikan dan Kebudayaan No. 070/0/1977 tanggal 15 Maret 1977, wilayah Sangiran dan sekitarnya ditetapkan sebagai Daerah Cagar Budaya (Hidayat, 2004). Diperkuat lagi dengan ketetapan yang dikeluarkan oleh komite World Heritage UNESCO pada peringatan yang ke-20th di Merida, Meksiko yang menetapkan Kawasan Sangiran sebagai Kawasan World Heritage (Warisan Dunia) No. 593. (Widianto dan Sadirin dalam Hidayat, 2004)

Berdasarkan hal tersebut, tulisan ini akan membahas mengenai tipologi pintu rumah tradisional Dusun Pucung. Hal ini dikarenakan belum adanya kajian tipologi yang mengkhususkan mengenai pintu rumah tradisonal, yang terletak dalam kawasan cagar budaya, atau terletak dalam kawasan pelestarian situs manusia purba. Elemen pintu dipilih karena pintu bagi masyarakat Dusun Pucung tidak hanya sebagai elemen fungsional, namun juga secara simbolis memiliki fungsi dan makna yang berbeda dari kaidah pintu pada umumnya.

\section{Tinjauan Teori}

\section{Tipologi}

Tipologi secara etimologi berasal dari kata typos yang berarti akar dari (the roof of) dan kata logos yang berarti pengetahuan atau ilmu, jadi tipologi adalah pengetahuan mengenai asal usul atau karakteristik dari suatu obyek (Budiharjo, 1984 dalam Sukada, 1997).

Moneo (1979) mengatakan tipologi berasal dari kata "tipe" yang didefinisikan sebagai konsep yang mendiskripsikan kelompok karakteristik obyek yang memiliki persamaan struktur formal.

Menurut Colquhoun (1967), tipologi sebagai instrumen dari memori kebudayaan, sebuah kondisi dari makna arsitektural.

Menurut Pfeifer dan Brauneck (2008) tipologi adalah sebuah pendekatan yang memisahkan atribut-atribut dari koherensi arsitektural, dan mengidentifikasinya sebagai sebuah karakteristik, dalam tujuan untuk mengkomparasikannya dengan atribut-atribut abstrak dari konteks yang lain, dan untuk mendefinisikan kesamaan atau perbedaan. Lebih lanjut, menurut Francescatto (1994) tipologi merupakan aktifitas atau kegiatan yang menghasilkan tipe sama dengan mengklasifikasikan dan mengkategorisasikan.

Tipologi adalah studi dari tipe-tipe elemen yang sudah tidak dapat direduksi lagi. Kata tipe dalam konteks arsitektur menjadi architype dan kemudian yang menjadi tipologi yang merupakan suatu tatanan paradigma dan alat yang dimiliki oleh arsitektur untuk menempatkan kedudukan arsitektur sebagai bidang ilmu pengetahuan (Johnson, 1994).

Durand (2000) dalam Precis of the Lectures on Architecture membagi tipologi dalam arsitektur menjadi 3, yakni: tipologi tradisional, tipologi (gerakan) modern, dan tipologi fungsional.

Fungsi dari kajian tipologi menurut Karen (1994) dalam Mochsen (2005) adalah digunakan untuk menerangkan perubahan-perubahan dari suatu tipe, dikarenakan suatu tipe memiliki ciri-ciri tertentu yang membedakannya dengan tipe yang lain. Berdasarkan pendapat Moneo (1979), tujuan tipologi adalah sebagai alat untuk melihat dan mempelajari obyek arsitektur. Dalam hal ini tipologi sebagai konsepsi sekaligus metode.

Dapat disimpulkan bahwa tipologi merupakan cabang pengetahuan atau wawasan yang menitikberatkan terhadap identifikasi tipe dan karakteristik, pengklasifikasian dan pengelompokan (taksonomi).

\section{Pintu}

Dalam Kamus Besar Bahasa Indonesia, pengertian pintu adalah tempat untuk masuk dan keluar. Ini berarti bahwa pintu adalah suatu benda penghubung untuk melakukan aktivitas memasuki sesuatu atau keluar dari sesuatu tempat. Jika dikaitkan dengan rumah tinggal maka pengertian pintu adalah tempat untuk keluar-masuk pada tempat tinggal manusia.

Pintu adalah sebuah bukaan pada 
dinding/bidang yang memudahkan sirkulasi antar ruang-ruang yang dilingkupi oleh dinding/bidang tersebut. Pintu biasanya ditemukan pada bangunan, misalnya rumah. Selain itu, pintu juga terdapat pada kendaraan, lemari, dan lain-lain Kebanyakan pintu terbuat dari kayu dan selebihnya, dalam penggunaan yang terbatas terbuat dari aluminium, besi dan plastic PVC. Pintu kayu terdiri dari beberapa jenis. Yang paling umum adalah pintu yang terbuat dari kayu utuh. Selain itu juga terdapat pintu kayu jenis "Flush", yang didalamnya terdapat ruang hampa. (http://id.wikipedia.org/wiki/Pintu Diakses 21 Mei 2012 Pukul 02.00 WIB).

\section{Metode Penelitian}

Tujuan dari penelitian tentang tipologi pintu rumah tradisional ini adalah untuk mengklasifikasikan pintu rumah yang berada dalam lingkup kawasan penelitian melalui identifikasi tipikal desain elemen pintu yang dapat dikategorikan kedalam fitur-fitur desain pintu.

Pendekatan penelitian dilakukan secara kuantititatif dan kualitatif.
Pengambilan data primer yang dilakukan melalui survey lapangan. Diiringi dengan studi literatur, studi kawasan, teoritikal, studi empiris terhadapt laporan penelitian terdahulu. Analisis data primer diawali dengan perumusan karakter umum pintu bangunan kawasan, penentuan pintu bangunan yang sesuai kriteria penelitian, penggambaran ulang (re-drawing), pengelompokan dan kategorisasi tipikal elemen pintu bangunan.

\section{Hasil dan Pembahasan}

Sangiran adalah sebuah daerah pedalaman yang terletak di kaki Gunung Lawu, tepatnya di depresi Solo sekitar 17 $\mathrm{Km}$ ke arah utara dari Kota Solo dan secara administatif terletak di wilayah Kabupaten Sragen dan sebagian terletak di Kabupaten Karanganyar, Propinsi Jawa Tengah. Luas wilayahnya $\pm 56 \mathrm{Km}^{2}$ yang mencakup tiga Kecamatan di Kabupaten Sragen yaitu Kecamatan Kalijambe, Kecamatan Gemolong dan Kecamatan Plupuh serta Kecamatan Gondangrejo di Kabupaten Karanganyar. Secara astronomi terletak pada $7^{\circ} 25^{\prime}-7^{\circ} 30^{\prime} \mathrm{LS}$ dan pada $4^{\circ}-7^{\circ} 05^{\prime}$ BT.

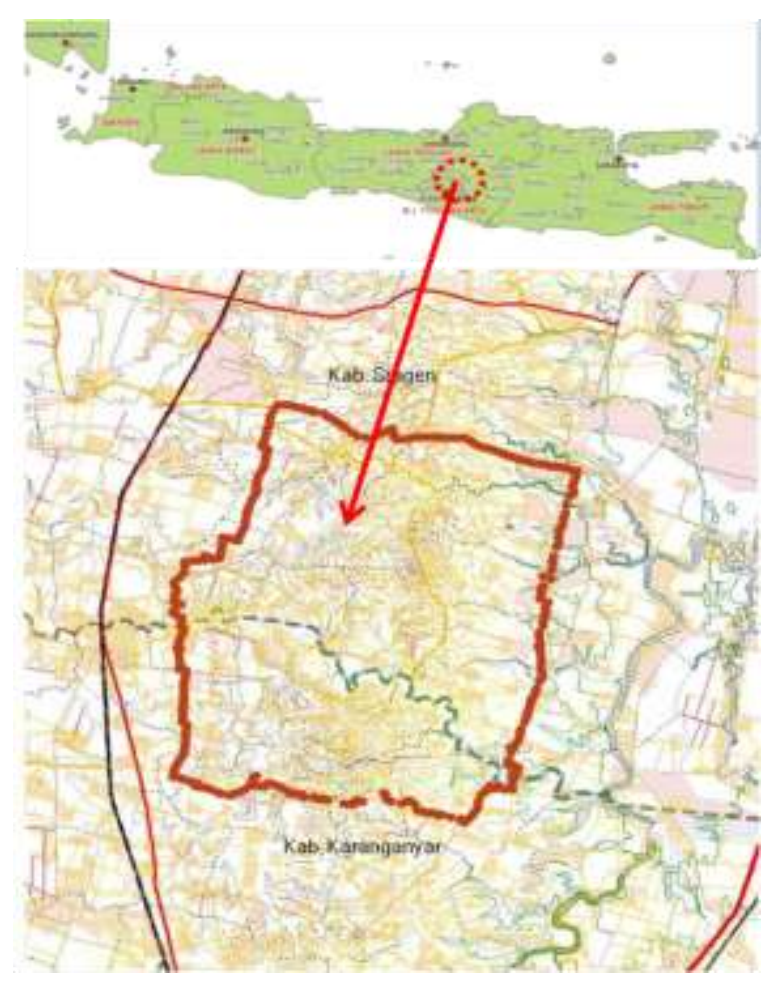

(Sumber: Balai Pelestarian Situs Manusia Purba Sangiran, 2012) Gambar 1. Peta Lokasi Kawasan Situs Manusia Purba Sangiran 

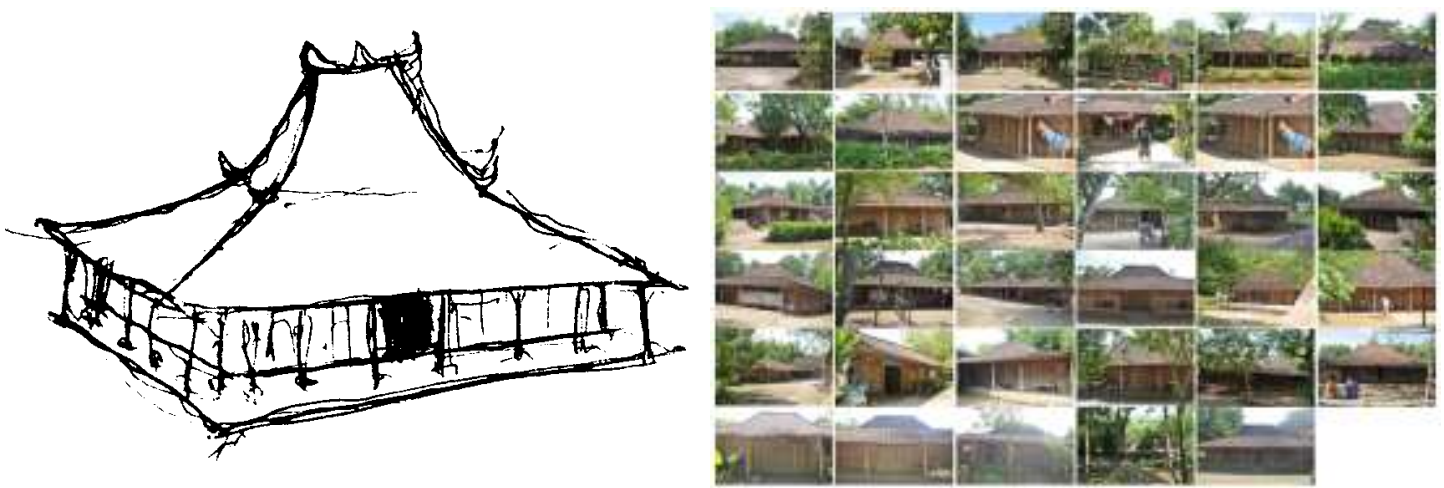

(Sumber: Sketsa dan Dokumentasi Penulis, 2012)

Gambar 2. Rumah Tradisional Jawa Dusun Pucung (kiri) Kompilasi Rumah Dusun Pucung (kanan)

Pemetaan tipikal desain dan elemen pintu pada bangunan di pemukiman Dusun Pucung Kawasan Konservasi Situs Manusia Purba Sangiran dapat dikategorikan kedalam dua fitur elemen yaitu: tipikal pintu berdasarkan jumlah dan tipikal pintu berdasarkan material pembuatnya.

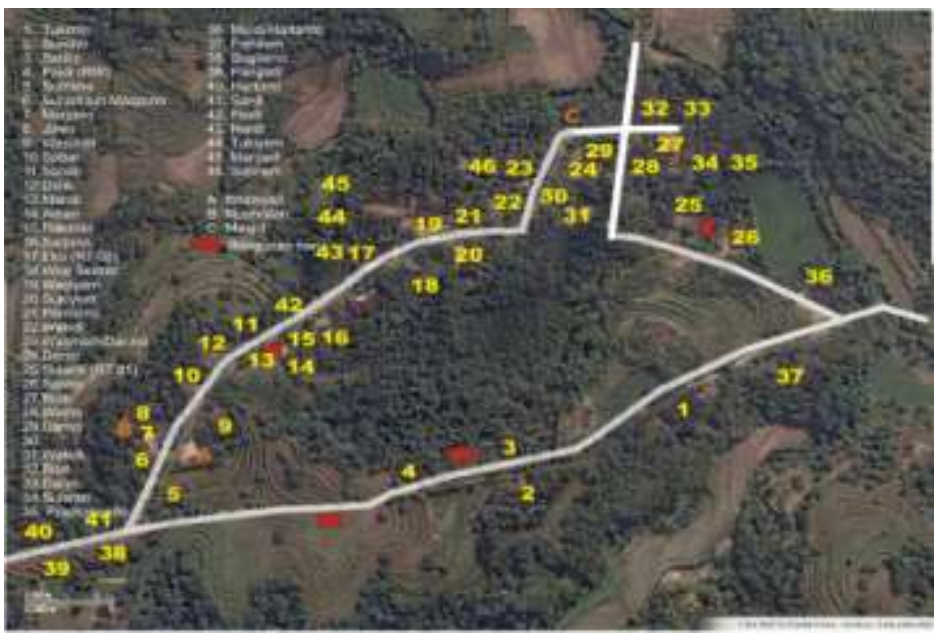

(Sumber: Kartikasari, 2012)

Gambar 3. Peta Pemukiman Dusun Pucung, Kawasan Situs Manusia Purba Sangiran

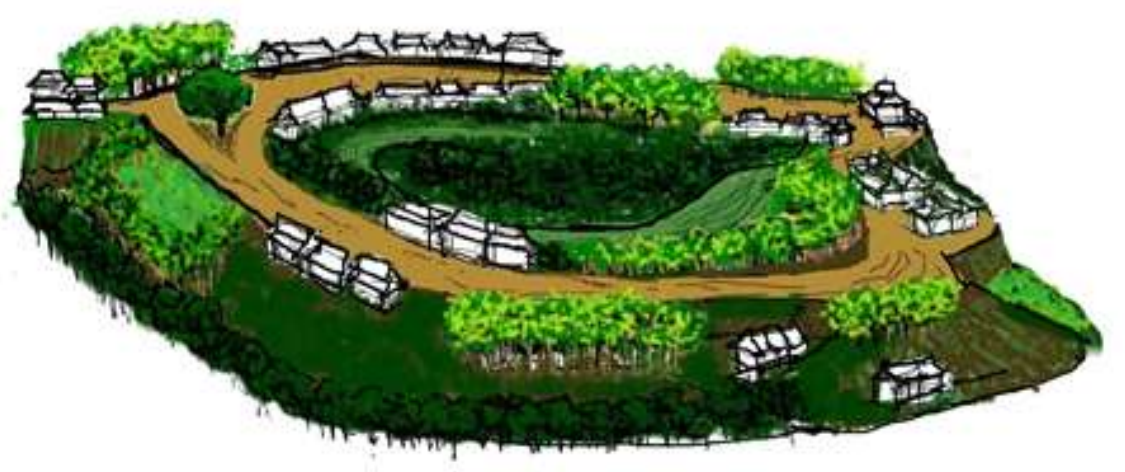

(Sumber: Kartikasari, 2012)

Gambar 4. Sketsa Persfektif Pemukiman Dusun Pucung, Sangiran

Pintu-pintu yang ada pada rumah tradisional masyarakat Desa Pucung memiliki jumlah yang berbea-beda antara rumah yang satu dengan rumah yang lainnya. Namun hal tersebut dapat dikategorikan kedalam 3 kategori. Yang mana pada satu sisi bangunan memiliki pintu berjumlah ganjil yaitu:
a) Pintu berjumlah 1 (satu)
b) Pintu Berjumlah 3 (tiga)
c) Pintu Berjumlah 5 (lima) 

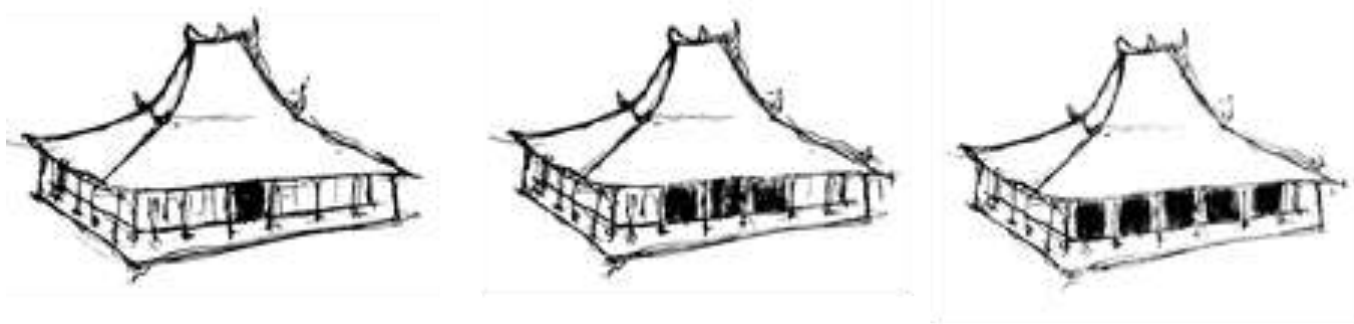

(Sumber: Sketsa Penulis, 2012)

Gambar 5. Rumah Tradisonal Dusun Pucung Berdasarkan Jumlah Pintunya
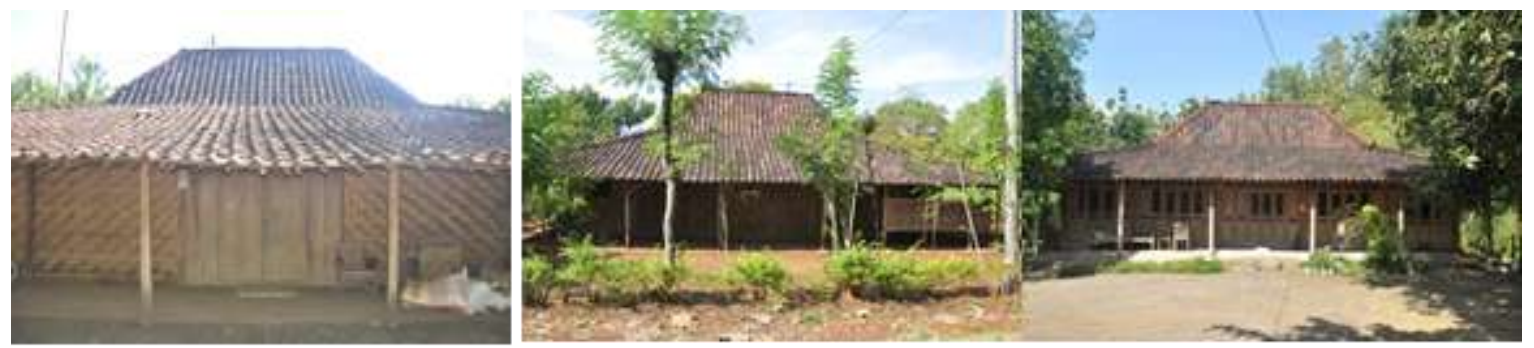

(Sumber: Dokumentasi, 2012)

Gambar 6. Ragam Pintu dengan Jumlah 1 (Satu), 3 (tiga), dan 5 (lima)

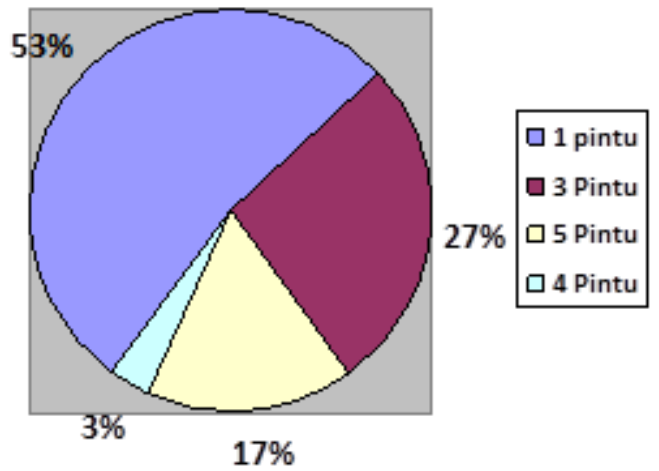

(Sumber: Analisis Penulis, 2012)

Gambar 7. Diagram Persentase Pintu berdasarkan Jumlahnya

Material

Pintu pada rumah-rumah tradisonal Dusun Pucung memiliki nilai estetis yang bermacam-macam. Adapun material yang digunakan dalam pembuatan desain pintu tersebut menggunakan bambu, kayu, maupun perpaduan antara kayu dan kaca. Yang mana pemilihan material pintu tersebut dibuat
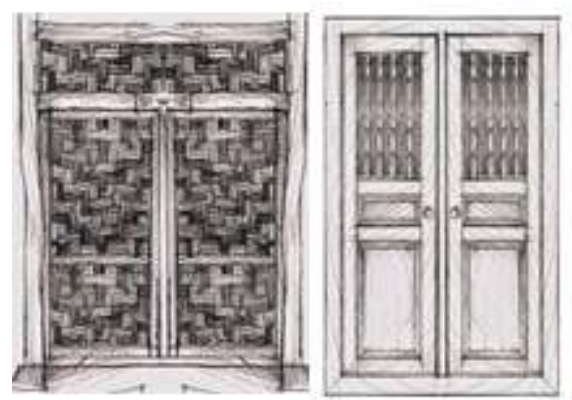

(Sumber: Sketsa Penulis, 2012)

Gambar 8. Sktesa Pintu Berdasarkan Materialnya pemilik rumah. kategori, yaitu: atau Gedhek dan kaca

berdasarkan kemampuan finansial

Oleh karena itu pintu berdasarkan materialnya dibedakan menjadi 3

a) Pintu dengan material bambu

b) Pintu dengan material kayu

c) Pintu dengan material dasar kayu

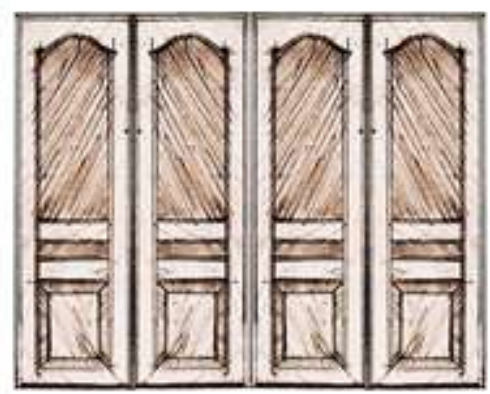

$$
\text { a }
$$


Bambu yang digunakan sebagai elemen dinding merupakan bambu yang dianyam kemudian disebut gedhek. Anyaman bambu tersebut memiliki beberapa pola anyaman yaitu, nam tabak, nam warek, nam durno, dan nam lengko. (wawancara dengan Bapak Sulardi, Sesepuh di Dusun Pucung, Pada tanggal

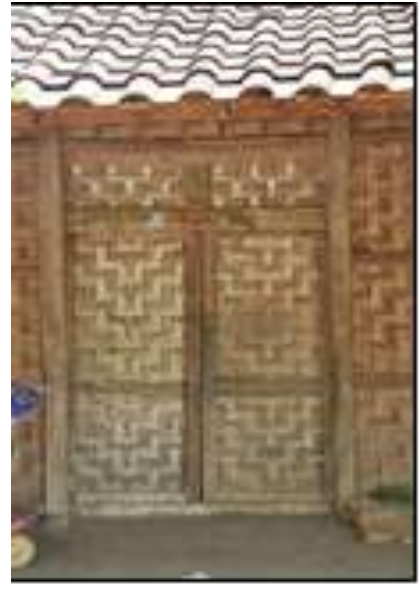

(Sumber: Dokumentasi, 2012)

Gambar 9. Ragam Pintu dengan Material Gedek

Bahan kayu, seperti kayu Jati Kebun, kayu Juar, kayu Waru, dan kayu Tekik didapatkan warga dari kebun miliknya sendiri, sedangkan kayu jati alas yang kualitasnya lebih bagus didapatkan warga dari para penjual kayu
6 Mei 2012).

Fakta di lapangan hanya ditemukan 2 tipe Pintu yang mengunakan material bambu atau gedhek pada rumah tradisional Dusun Pucung, yaitu Pintu dengan material gedhek pola anyaman nam tabak, nam warek, nam durno, dan nam lengko.

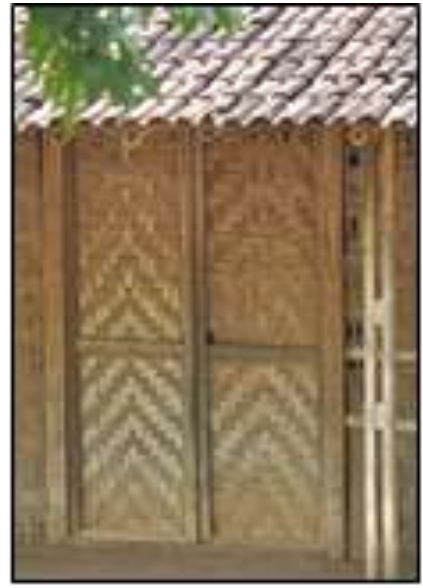

gelondongan.

Penggunaan material kayu tersebut memiliki beragam variasi bentuk pintu, seperti gambar dibawah ini. Ada 5 tipikal pintu yang terdapat pada rumah tradisional Dusun Pucung.



(Sumber: Dokumentasi, 2012)

Gambar 10. Ragam Pintu dengan Material Kayu

Kombinasi kayu dan kaca merupakan tipe pintu yang sangat sedikit digunakan oleh masyarakat Dusun Pucung, hal ini disebabkan oleh mahalnya material kaca dan kayu tersebut. Masyarakat Dusun Pucung mendapatkan pintu dengan material kayu dan kaca tersebut dengan cara membeli dari toko perabotan.

Adapun tipe pintu tersebut yaitu pintu setengah panel, setengah kaca. Memiliki bentuk panel kayu dibagian bawah dan setengah bagian atasnya diberi kaca. 


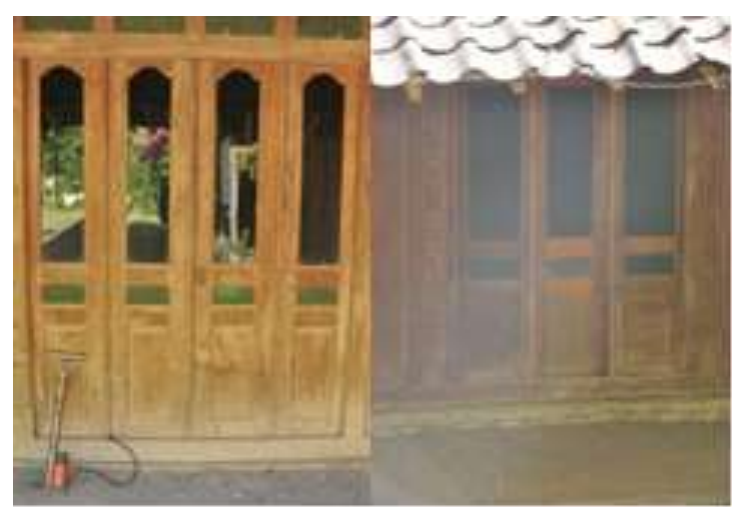

(Sumber: Dokumentasi, 2012)

Gambar 11. Pintu dengan Panel Kayu dan Kaca

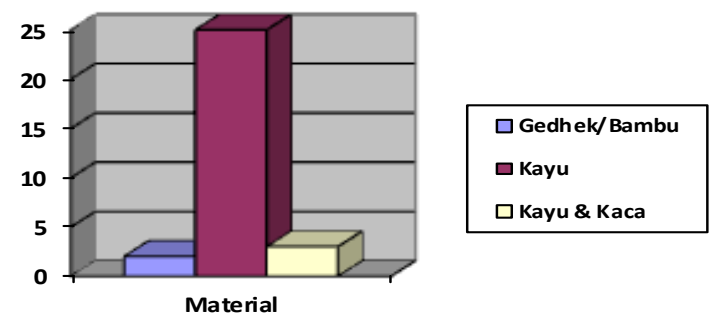

(Sumber: Analisis Penulis, 2012)

Gambar 12. Diagram Pintu Berdasarkan Materialnya

Pintu Sebagai Penanda Strata Sosial

Penggunaan pintu pada permukiman dusun pucung juga sebagai penanda strata sosial ekonomi masyarakat. Penggunaan pintu dengan material gedheg atau bambu di gunakan oleh masyarakat yang berekonomi lemah, dengan hanya menggunakan 1 (satu) pintu. Kemudian penggunaan pintu dengan material kayu, digunakan oleh masyarakat kalangan ekonomi menengah, jumlah pintunya berjumlah 3 (tiga). Sedangkan penggunaan pintu dengan material kayu dan kaca, beserta ornamen pada pintu digunakan oleh masyarakat yang berekonomi lebih mapan, yaitu berjumlah 5 (lima) pintu.

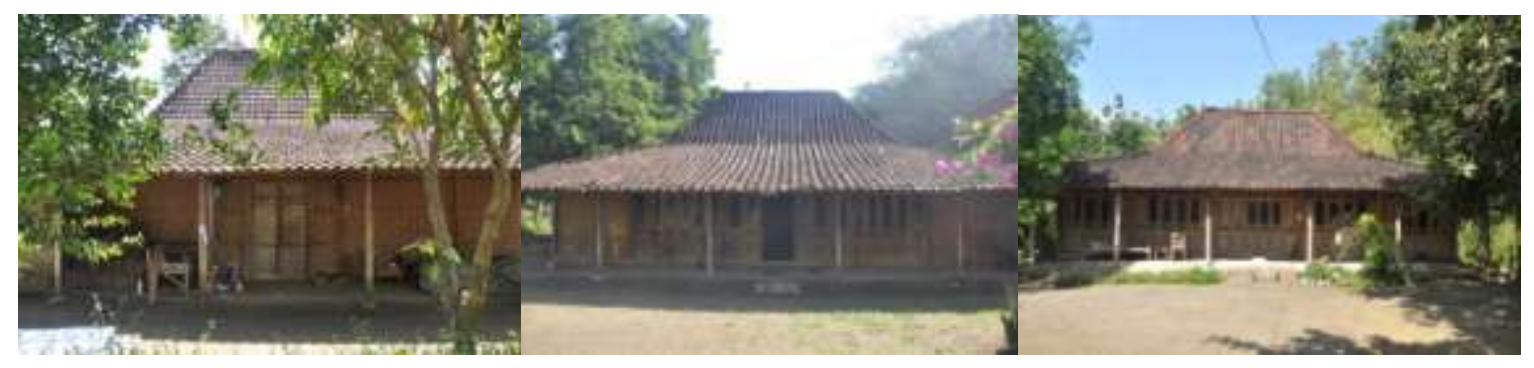

(Sumber: Dokumentasi, 2012)

Gambar 13. Ragam Pintu dengan Tingkatan Strata Sosial Pemiliknya 

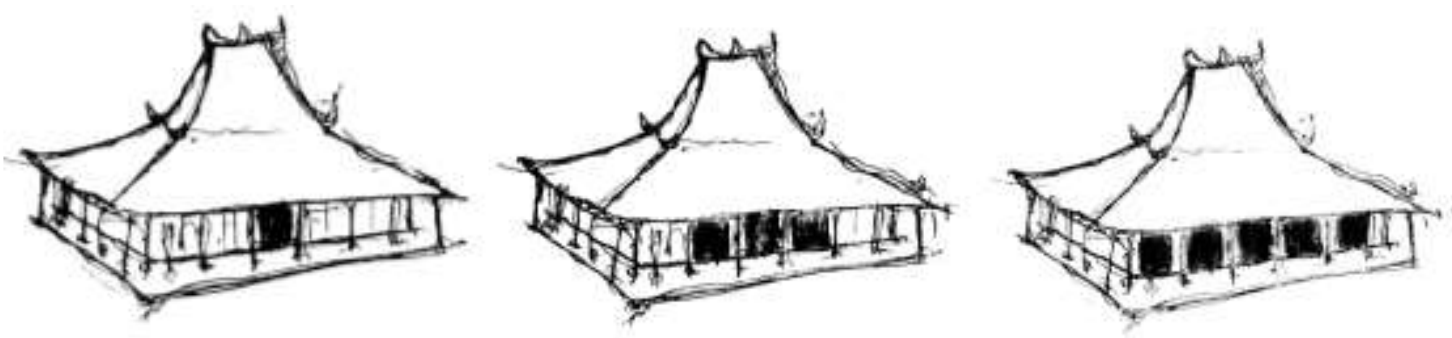

(Sumber: Sketsa Penulis, 2012)

Gambar 14. Jumlah Pintu Memberikan Suatu Kebanggaan Bagi Pemilik Rumah

Fungsi Pintu

Fungsi pintu pada rumah Dusun Pucung sebagai tempat untuk masuk dan keluar. Pintu adalah suatu benda penghubung untuk melakukan aktivitas. Memasuki sesuatu atau keluar dari sesuatu tempat, jalur sirkulasi antara ruang-ruang dalam rumah dengan halaman luar bangunan.

Pintu yang berjumlah banyak biasanya digunakan pada saat hajatan, dimana semua pintu di buka untuk tamu, yang mana disini berarti dalan hajatan ini tamu diundang untuk masuk kedalam rumah dari sisi manapun. Kemudian semua pintu tersebut dibuka pada saat lebaran, dimana pintu terbuka untuk keluarga, disimbolkan bahwa pintu maap selalu terbuka.

\section{Anomali}

Adanya 1 (satu) rumah dengan pintu yang berjumlah genap, yaitu berjumlah 4 (empat). Berbeda dengan pintu yang lain dimana berjumlah ganjil, 1,3 , dan 5 , hal ini sangatlah menarik untuk diperhatikan.

Kemudian setelah dilakukan wawancara lebih mendalam, penggunaan pintu berjumlah 4 ini lebih dikarenakan oleh kemampuan finansial sang pemilik rumah.

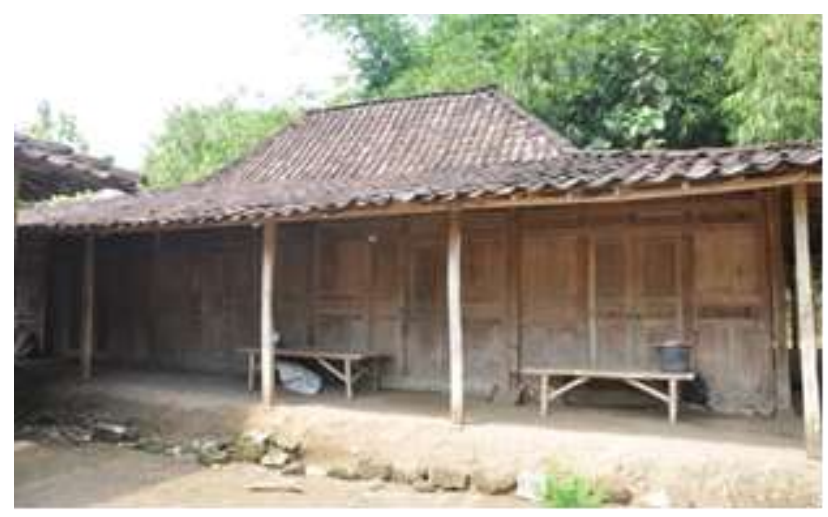

(Sumber: Dokumentasi, 2012)

Gambar 15. Rumah dengan pintu berjumlah Genap/Empat

\section{Kesimpulan dan Saran}

Tipologi bangunan suatu pemukiman akan membuka wawasan akan pengertian dan pemahaman lebih jauh terhadapat karakter kehidupan masyarakat yang berada dan berkembang serta beradaptasi terhadap lingkungan sekitarnya. Sikap dan nilai budaya merupakan faktor yang turut serta dalam membentuk dan mewarisi nilai-nilai rancang bangun yang terus berkembang.

Penelitian ini pada akhirnya dapat mentipekan desain elemen pintu rumah tradisional yang berada di kawasan konservasi Situs Manusia Purba Sangiran, yang termasuk kedalam kawasan World Heritage. Berdasarkan hasil penelitian, didapatkan 6 (enam) tipe 
pintu rumah tradisional Dusun Pucung. Tipe pintu tersebut berdasarkan 2 kategori, yaitu berdasarkan jumlah dan berdasarkan materialnya.

Variasi bentuk pintu dan fitur elemen desain pintu bangunan merupakan bukti nyata bagaimana nilai arsitektural tersebut dapat tumbuh dan berkembang ditengah masyarakat tradisional.

Namun bukan berarti keberadaan pemukiman yang tepat berada dalam kawasan inti Balai Pelestarian Situs Manusia Purba tidak boleh berkembang, Penghidupan yang layak dan hak untuk mengembangkan Rumah kearah yang lebih baik tidak boleh dibatasi, walaupun pemukiman tersebut terletak di kawasan World Heritage.

\section{Referensi}

Balai Pelestarian Situs Manusia Purba Sangiran. (2012). Brosur 'Museum Purbakala: Situs Sangiran (Perjalanan Menakjubkan Kembali ke Zaman Purba), Kantor Pariwisata, Investasi, dan Promosi Pemkab Sragen. Sragen, Jawa Tengah

Colquhoun, A.. (1967) Typology and Design Method, dalam Theorizing a New Agenda for Architecture. An Anthology of Architectural Theory 1965- 1995, Kate Nesbitt (ed.). Princeton Architectural Press. New York
Durand, Jean Nicolas Louis. (2000). Pr'ecis of the Lectures on Architecture. The Getty Research Institute. Los Angeles

Francescatto, Guido. (1994) Type and the Possibility of an Architecture Scolarship, Ordering Space, Types in Architectural and Design, Karen A. Franck, Lynda $\mathrm{H}$. Schneekloth (ed). Van Nostrand Reinhold. New York

Hidayat, Rusmulia Tjiptadi, dkk. (2004) Museum Situs Sangiran: Sejarah Evolusi Manusia Purba Beserta Situs dan Lingkungannya. Koperasi Museum Sangiran. Sangiran.

Johnson. P A. (1994). The Theory of Architecture, Van Nostrand Reinhold Company. New York

Kartikasari, Indah. (2012). Topografi Dusun Pucung, Situs manusia Purba Sangiran. Laporan Penelitian KKA-S2 UGM 2012. Yogyakarta

Mochsen, Sir Mohammad. (2005). Tipologi Geometri: Telaah Beberapa KaryaFrank L. Wright dan Frank O. Gehry, Rona Jurnal Arsitektur Volume 2, No. 1 April 2005 hal 6983. FT Unhas. Makasar

Moneo, Rafael. (1979) Oppositions Summer On Typology. A Journal for Ideas and Criticism in Architecture vol. 13 h. 23-45. The MIT Press. Massachusetts

Pfeifer, G.; P. Brauneck. (2008). Courtyard Houses-A Housing Typology. Birkhauser Verlag AG. Germany

Sukada, B. (1997). Memahami Arsitektur Tradisional dengan Pendekatan Tipologi. PT. Alumni. Bandung 